\title{
The influence of personal and organisational factors on entrepreneurship intention: An application in the health care sector
}

\author{
Carla S. Marques PhD in Management, Assistant Professor ${ }^{1}$ (D) | Sandra Valente Master in \\ Management of Healthcare Services, Nurse ${ }^{2}$ | Marisa Lages PhD in Management, Invited \\ Assistant Professor ${ }^{3}$
}

${ }^{1}$ UTAD and Centre for Transdisciplinary Development Studies (CETRAD) Research Unit, Vila Real, Portugal

${ }^{2}$ Centro Hospitalar de Trás-os-Montes e Alto Douro, Vila Real, Portugal

${ }^{3}$ University of Trás-os-Montes and Alto Douro (UTAD), Vila Real, Portugal

\section{Correspondence}

Carla S. Marques, UTAD and Centre for Transdisciplinary Development Studies (CETRAD) Research Unit, Vila Real, Portugal. Email: smarques@utad.pt

\section{Funding information}

European Regional Development Fund's 'Competitiveness and Internationalization' Operational Program, Grant/Award Number: UID/SOC/04011; Portuguese Foundation for Science and Technology, Grant/Award Number: UID/SOC/04011/2013
Aims: This study sought to contribute to research on entrepreneurial intention by identifying which constructs of the entrepreneurial profile and internal conditions of health care organisations support entrepreneurship and contribute to the entrepreneurial intention of these organisations' employees.

Background: In addition to psychological attributes, cognitive processes, motivations, sociodemographic and professional characteristics, and entrepreneurial skills, the literature indicates that internal conditions of organisations also contribute to explaining entrepreneurial intention.

Methods: To evaluate this model empirically, the primary data were collected with questionnaires distributed to nurses in two public hospitals-the Trás-os-Montes and Alto Douro Hospital Center and the Local Health Unit of the Northeast. A total of 638 nurses filled out the questionnaire. The data were analysed using inferential and regression analyses.

Results: The results suggest that the dimensions related to personal attributes, namely, motivation and entrepreneurial skills, are the constructs that best explain the entrepreneurial intention of these professionals within their organisations.

Conclusions: A broad discussion is needed about how to implement internal conditions that promote an intrapreneurial and innovative culture in health care organisations.

Implications for Nursing Management: Health care organisation administrators need to prioritise intrapreneurship while structuring their management strategies, thereby creating favourable internal conditions (e.g., support, autonomy, rewards, time availability and appropriate organisational procedures) that enhance their nurses' entrepreneurial intention.

\section{KEYWORDS}

entrepreneurial profile, entrepreneurship intention, health organisations, intrapreneurship, nurses 


\section{AIMS}

Society is currently experiencing an era of extensive entrepreneurship, dominated not only by increased entrepreneurial activity but also a fundamental change in the way of thinking about life, organisations and the environment. The concept of intrapreneurship has emerged, which can be defined as the way organisations can be transformed from the inside to become more profitable when employees that are more visionary are allowed to implement their entrepreneurial ideas. Any organisation can benefit from sustaining and encouraging entrepreneurship because, through entrepreneurship, organisations can develop, reinvent themselves, improve their performance and ensure survival in the marketplace (Cadar \& Badulescu, 2015). To this end, organisations must enhance their employees' entrepreneurial profile, as well as the internal organisational conditions that foment an entrepreneurial culture.

A few differences have been identified between the profiles of entrepreneurs and intrapreneurs. Entrepreneurs are considered agents of change-innovators who produce new products, identify new markets, combine resources in ways that lead to new and unique modes of competitive advantage, and create changes in the rules of market competitiveness. In contrast, intrapreneurs seek to change the current state of their organisation and innovate within this context, which requires an organisational culture and environment that encourages successful intrapreneurship (Smith, Rees, \& Murray, 2016).

An internal work environment that rewards and recognises employee discretion-combined with the appropriate level of organisational boundaries, such as formalisation, centralisation, technological routines and connectivity-is crucial to fostering organisational culture and job satisfaction. These, in turn, can lead to the development of entrepreneurial orientation and intentions within organisations (Karyotakis \& Moustakis, 2016).

Entrepreneurship intention (EI) has been considered a significant construct in the most recent research on entrepreneurship, based on the evidence that El predicts future entrepreneurial activity even in the long term (Liñán \& Fayolle, 2015). Some studies have already related El to entrepreneurial skills (e.g., Adeyemo, 2009; Ibrahim \& Lucky, 2014), taking into account personal characteristics and context factors (e.g., Karimi et al., 2017; Singh, Verma, \& Rao, 2016). However, only a few studies have been conducted in health care organisations (e.g., Lages, Marques, Ferreira, \& Ferreira, 2016) and specifically involved the growing number of nurses who are part of change processes in different areas of health care activities (e.g., Sankelo \& Åkerblad, 2008). Erdmann et al. (2009, p. 642) suggested:

The visibility of ... nurse[s] is ... [increased] by ... [a] search of the interactive and associative possibilities of [their] social contribution[s] in ... different spaces and fields of action, in order to broaden and make known ... [nurses'] field of intervention.

According to DeSantis and Scales (2015), nurses have an extremely important role in the health care system. However, to engage in innovative behaviour, nurses need management support, resources, a favourable work environment and knowledge about innovation and the role of nurses. Nursing leadership is, thus, vital to the development of nursing practices, fostering and supporting the level of intensity required for innovation processes in health care organisations.

Taking into account the aforementioned research, the present study had as its main objective to identify which constructs of the entrepreneurial profile and internal conditions of organisations promote the El of a specific group of health professionals, namely, nurses. Based on this research objective, this study addressed the following question: How do personal and organisational factors influence nurses' El?

The focus of this study was justified by the lack of studies in this area, which was confirmed by bibliographical research in international data bases, such as Web of Science and Scopus. This gap included the need for a fuller understanding of the relationships between the entrepreneurial profile, health care organisations' internal conditions and health care professionals' El-in this case, nurses. Although, intrapreneurial research has been around for more than 25 years, surprisingly, Jong and Wennekers (2008) and Bosma, Stam, and Wennekers (2011) found that this field of research is still quite restricted.

In health care organisations, intrapreneurship can be considered a great opportunity to develop competitive advantages. It is also a way to improve the health care of patients, raising innovation levels and constantly transforming organisations. A particularly important benefit is that intrapreneurship offers a method to make the most of each employee-intrapreneur's potential (Kuratko, Hornsby, \& Covin, 2014).

In the specific case of health organisations, few studies in this area have encompassed research on entrepreneurship, in general (Lages et al., 2016; Marques, Ferreira, Ferreira, \& Lages, 2013), and on nurse entrepreneurship, in particular (Costa et al., 2013; Sankelo \& Åkerblad, 2008). The present study, therefore, sought to provide top administrators and middle managers of health care organisations with the information needed to develop conditions that could foster their nurses' intrapreneurial intentions. This represents an opportunity for nurses to differentiate how they exercise their profession in workplace activities from other organisations' employees, thereby promoting better performance in health care organisations and increasing nurses and clients' satisfaction.

After this introduction, a brief theoretical discussion of $\mathrm{El}$ and related factors is provided. Section 3 describes the methodology used. In the fourth section, the results are presented, followed by the final sections' discussion of findings and this study's limitations and implications.

\section{BACKGROUND}

\section{1 | Entrepreneurship intention}

Intention can be interpreted as an indication of how willing an individual is to try something and how much effort he or she is willing to expend to engage in certain behaviours for a particular length of time (Kusmintarti, Thoyib, Maskie, \& Ashar, 2016). The decision to become an entrepreneur needs to be considered voluntarily and consciously 
(Krueger, Reilly, \& Carsrud, 2000), so, logically, how this decision is made needs to be analysed (Liñán \& Chen, 2009).

Within the field of entrepreneurship, El is already a consolidated area of research (e.g., Fayolle \& Liñán, 2014), with a growing number of entrepreneurship studies using this construct as a powerful theoretical reference (e.g., Liñán \& Fayolle, 2015). According to Fayolle and Liñán (2014), the work done by Shapero and Sokol (1982) and Shapero (1984) marks the period in which the literature on El started its rapid growth (e.g., Fayolle \& Liñán, 2014; Fayolle, Liñán, \& Moriano, 2014).

On a practical level, El can be defined as an individual's selfrecognised conviction that he or she intends to start a new business and consciously plans to do so at some point in the future (Thompson, 2009). Ibrahim and Lucky (2014) defined El as a set of ideas that guide, co-ordinate and control the action of creating and developing a new business, including its implementation and the evaluation of the external or internal environments of relevant organisations.

In general, Els depend on perceptions of the personal attractiveness and social norms of the viability of entrepreneurship, but some authors also mention that Els depend on perceptions of personal convenience and viability, as well as individuals' propensity to act (Krueger et al., 2000). For a variety of authors (Ismail et al., 2015; Krueger et al., 2000), studying El helps to understand its antecedents and to anticipate this intention (Ibrahim \& Lucky, 2014). Therefore, one of the dimensions chosen for the present study was to examine the El of a specific group of health care professionals-nurses-to identify the antecedents of their Els.

\subsection{1 | Internal conditions of organisations}

A set of conditions can be identified that make the internal environment of an organisation more welcoming to entrepreneurial attitudes. Most of these conditions are associated with the openness with which organisations deal with their employees, as well as the incentives administrators provide for employees to develop an entrepreneurial culture within the organisation (e.g., Antoncic \& Hisrich, 2003). Bhardwaj (2012) argue that, by giving appropriate rewards to employees, intrapreneurial activity can be improved. An effective reward system needs to consider goals, feedback, result-based incentives and an emphasis on individual responsibility. Currently, dynamic and soft conditions advocate work environments that encourage new ideas, innovation, proactive behaviour, risk-taking, rational management, rewarding experiments, maturity, willingness to change and open-mindedness (Karyotakis \& Moustakis, 2015).

Several researchers have recognised the importance of internal organisation conditions in promoting and supporting the development of an entrepreneurial environment (Hornsby, Kuratko, Shepherd, \& Bott, 2009; Kuratko, Ireland, \& Hornsby, 2001). Notably, the size and type of organisation (i.e., public, private or non-profit) influence the internal conditions that the organisation provides its employees (Zapkau, Schwens, Steinmetz, \& Kabst, 2015). Kuratko et al. (2014) identify five specific dimensions that contribute to an environment that encourages entrepreneurial behaviour: manager and/or co-ordinator support, autonomy, rewards, availability of time, and organisational procedures. Therefore, the following research hypothesis was proposed:

$\mathrm{H}_{1}$ : The internal conditions of a health care organisation foster the El of nurses.

\subsection{2 | Sociodemographic and socio- professional factors}

Previous research on El has identified some factors related to individuals' intention to start a business, including social aspects, socioprofessional contexts (e.g., Karimi et al., 2017; Nabi \& Liñán, 2011), and sociodemographic aspects, such as gender and training (e.g., Phipps, Prieto, \& Kungu, 2015). Regarding gender, several studies highlight the impact of gender on El and gender differences among entrepreneurs (e.g., Pejić Bach, Merkač Skok, \& Suša, 2016).

Liñán, Cohard, and Cantuche (2011) refer to several determinants of El, including demographic factors such as age, gender, education and work experience. With regard to the target organisations of this study (i.e., health care institutions), a multitude of factors can stimulate intrapreneurship in these organisations, among which are social, administrative, demographic, professional and educational aspects.

Individual and sociocultural factors have a significant explanatory power for entrepreneurial intent and the decision to start a business (Darbyshire, 2014; Singh et al., 2016). Based on these findings, the following hypothesis was formulated:

\section{$\mathrm{H}_{2}$ : Sociodemographic and professional characteristics in- fluence the El of nurses.}

\subsection{3 | Psychological and cognitive factors}

Despite some scepticism in the past, personality traits continue to attract considerable attention in entrepreneurship research. Studies of psychological and/or personality factors have revealed the complexities inherent in personality and cognition, with different types of variables influencing the way people see, interpret and react to reality (Liñán \& Fayolle, 2015).

Individuals' personality influence their behaviours and attitudes. As the decision to start a business is a human behaviour, it is influenced by psychological factors (Chedli, 2016). In their studies in the health care sector, Lages et al. (2016) and Marques et al. (2013) identified the psychological factors of creativity and/or innovation, self-esteem and/ or self-confidence, and self-autonomy. In the present study, based on the review of the literature discussed above, the following research hypothesis was proposed:

$\mathrm{H}_{3}$ : Psychological factors influence the El of nurses.

The cognitive approach emphasises the fact that everything humans do or say is influenced by mental processes, motivations, perceptions or 


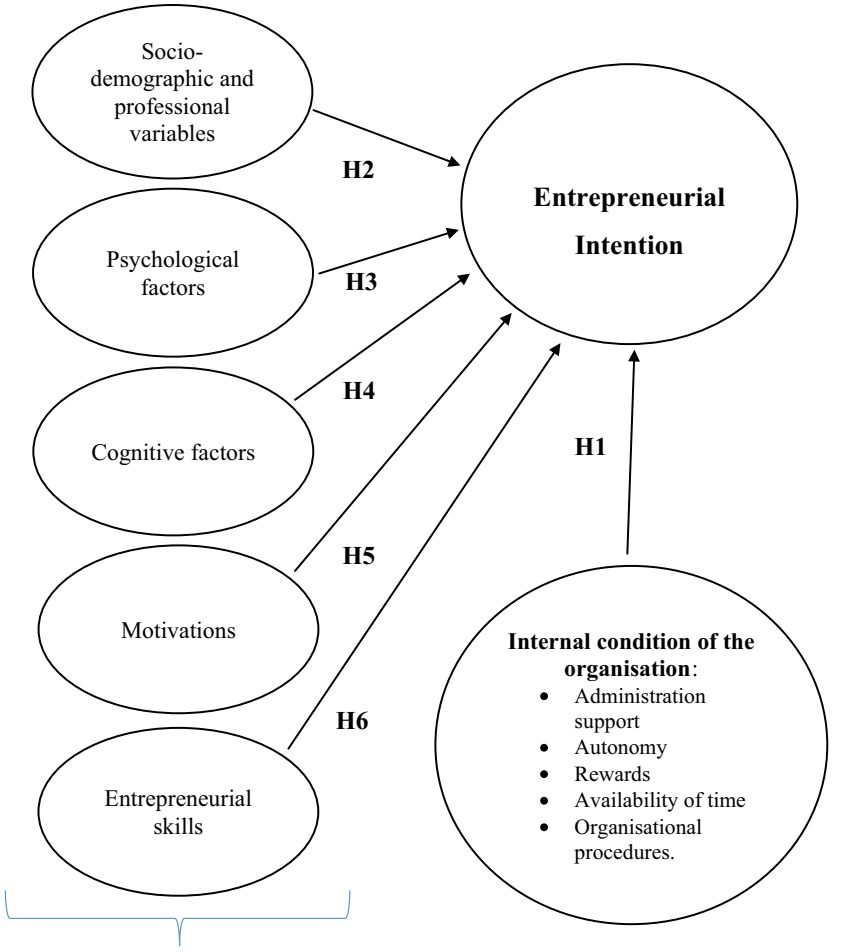

Constructs of the (intra) entrepreneur profile of the collaborators (nurses).

FIGURE 1 Conceptual model [Colour figure can be viewed at wileyonlinelibrary.com]

attitudes. Through these processes, people acquire information and then store, transform and use it to achieve different goals, make decisions or solve problems (Fernandéz, Liñán, \& Santos, 2009). Entrepreneurial cognition focuses on entrepreneurs' mental models and on the ways they link their psychological traits to entrepreneurial processes and outcomes (Chen, Chang, \& Lo, 2015; Virick, Basu, \& Rogers, 2015).

Tang, Tang, and Lohrke (2007) and Lages et al. (2016) refer in their studies to factors such as perseverance, an optimistic perception of success and the influence of affective states as cognitions that influence entrepreneurial behaviour. Muehlfeld, Urbig, and Weitzel (2017) confirm that one characteristic typically attributed to entrepreneurs is perseverance, namely, their commitment to a chosen path and fearless pursuit despite adversity (e.g., Baron, 2004; Holland \& Shepherd, 2013; Patel \& Thatcher, 2014; Verheul, Thurik, Grilo, \& Van der Zwan, 2012).

In the present study, the cognitive attributes associated with the profile of the health care professionals under study were: (1) optimistic perception of success; (2) perseverance; and (3) influence of affective states. Based on this line of thought, the following hypothesis was formulated:

$\mathrm{H}_{4}$ : Cognitive factors influence the $\mathrm{El}$ of nurses.

\subsection{4 | Motivational factors}

Chedli (2016) lists a number of motivational factors that influence entrepreneurial behaviour, which fall into two categories: (1) psychological motivations, such as personality traits and satisfaction of personal needs, and (2) contextual motivations, such as sociological interactions between individuals and their environment, situations, economic settings and government aid. Debarliev, Janeska-Iliev, Bozhinovska, and Ilieva (2015) study identified three motivational factors, personal attitude, perceived behavioural control and subjective norms, which have a positive impact on El.

Romero-Martínez and Milone (2016), in turn, report that autonomy at work, self-actualisation and the need to find an alternative to unemployment are the main motivations for entrepreneurship. Research by Indarti and Rostiani (2008) identified a desire for self-realisation as a determinant of El. Taking into account the health care organisations and professionals involved in the present study, autonomy and selfactualisation were considered determining variables for intrapreneurial intent. Thus, the following hypothesis was proposed:

\section{$\mathrm{H}_{5}$ : Motivations for intrapreneurship influence the $\mathrm{El}$ of nurses.}

\subsection{5 | Entrepreneurial skills}

Capacity is seen not so much as a quality in which performance depends fundamentally on individuals' innate capacities but instead, as something that needs to be developed through training, practice and experience. Entrepreneurial skills are necessary basic skills that enable individuals to start and successfully develop a financially viable business (Adeyemo, 2009). Ibrahim and Lucky (2014) also observed that entrepreneurial skills are an important factor for the development of successful entrepreneurship and that these are related to entrepreneurs' El.

According to Ibrahim and Lucky (2014), in the context of entrepreneurship, capacity has been identified as one of the most important and necessary factors in becoming entrepreneurs and being successful in entrepreneurial activities, including as a characteristic of those who intend to become entrepreneurs. Phipps et al. (2015) emphasise that individuals need relevant knowledge and skills for their intrapreneurial intentions to succeed. Therefore, the following research hypothesis was formulated:

\section{$\mathrm{H}_{6}$ : The entrepreneurial skills of nurses positively influence} their IE.

\section{2 | Conceptual model}

Based on the objective and research hypotheses presented in the previous subsections, the conceptual research model in Figure 1 was proposed. This model included the conceptualisation and incorporation of relevant dimensions from the following studies: Tang et al. (2007), Lages et al. (2016), Liñán (2008), Liñán and Chen (2009) and Marques et al. (2013). The independent dimensions were divided into two groups, as can be seen in the research model: 
(1) factors that are part of the entrepreneurial profile, and (2) factors that derive from the internal conditions of organisations.

\section{3 | METHODS}

The study population consisted of registered nurses in the Order of Nurses who work at the Hospital of Tras-os-Montes and Alto Douro (CHTMAD). This hospital comprises the Vila Real, Chaves, Lamego and Régua Hospitals, although the latter closed during the course of the study. This study also included the Local Health Unit of the Northeast (ULSNE), which consists of the Bragança, Mirandela and Macedo de Cavaleiros Hospitals and health care centres. The final sample was the nurses who were available to fill out the questionnaire. This was distributed to the nurses by mid-level nurse managers of the relevant services.

The questionnaire and the request to conduct the survey were evaluated and approved by the Administration and Commission of Ethics of CHTMAD and ULSNE. The five-part questionnaire contained closed-ended, multiple-choice questions with answers using a fivepoint Likert-type scale. The anonymity of the study participants was safeguarded to ensure ethical principles, and the data were treated using methods that guaranteed confidentiality. The inclusion criterion used was the nurses who worked in the health care organisations under study (i.e., CHTMAD and ULSNE). In the two public hospitals involved in this study, 1,384 questionnaires were distributed-823 in CHTMAD and 561 in ULSNE-in the first half of 2016. In total, 638 valid questionnaires were collected for a response rate of $46.10 \%$.

The scales used were validated by previous studies. More specifically, the scale of psychological and cognitive factors was taken from Lages et al. (2016) and Marques et al. (2013) work in health care organisations in Portugal. The entrepreneurial skills scale was originally developed by Liñán (2008) and translated and retranslated for the present study. The El scale was based on the one used by Liñán and Chen (2009), and the scale of organisations' internal conditions came from Lages et al. (2016) study of health care organisations in Portugal.

The validity of the scales for all the dimensions under study was evaluated using principal components factor analysis. Given the implementation of principal components factor analysis, the Kaiser-MeyerOlkin (KMO) test and Bartlett's test of sphericity became necessary. In addition, the internal reliability of the dimensions was evaluated using Cronbach's $\alpha$. IBM's SPSS AMOS software was used to carry out confirmatory factor analyses of the dimensions related to the psychological profile, internal conditions of organisations, entrepreneurial skills and El.

The hypotheses developed for this study were tested via analyses of multiple linear regression coefficients and their respective statistical significance using a stepwise algorithm. In addition to these calculations, the explanatory capacity of the models (i.e., adjusted $r$-squared), the validity and suitability of the models for the data (i.e., analysis of variance), and possible multicollinearity problems (i.e., the condition index value) were analysed.

\section{4 | RESULTS}

\section{1 | Characterisation of sample}

According to its 2014 annual report and accounts, CHMTAD employed 823 registered nurses with a mean age of 42.79 years, who mostly have an undergraduate degree and permanent employment in this institution. ULSNE's 2014 financial report listed 571 nurses on call to perform duties, of whom $58 \%$ were under 45 years old and most of whom have a permanent contract with the organisation.

This research dealt with a sample of participants in a feminised health care profession (i.e., 79.9\% of respondents are female): gender, $n=606$, who were mostly married or in a civil union; marital status, $n=606$. In terms of age, $70.9 \%$ of the respondents were over 36 years old; age, $n=619$. Regarding qualifications, $85.3 \%$ of the sample has a higher education degree and $12.6 \%$ have master's degree academic qualifications: $n=617$. The data also revealed that only $18.2 \%$ of the participants were trained in management; management training, $n=604$. The majority (62.4\%) of the nurses worked in CHMTAD and $37.6 \%$ in ULSNE, dispersed across several hospital units: institution where you work, $n=619$. Almost $40 \%$ of the sample was concentrated in the Vila Real Hospital. In terms of employment status, $88.6 \%$ of the respondents had a permanent contract, while $10.9 \%$ have a fixed-term contract; type of link to main institutions, $n=612$.

\subsection{Validation of research instrument}

Table 1 presents the results of the factorial analysis of the main components of the factors of organisations' internal conditions. These present acceptable results in adequacy and internal reliability that are always above the required minimum.

The factor analysis of the main components for the cognitive profile items led to the retention of three factors: optimistic perception of success (five items; Cronbach's $\alpha=.733$ ), perseverance (two items; Cronbach's $\alpha=.645$ ) and influence of affective states (one item) with acceptable results for internal reliability $(\mathrm{KMO}=.754$; Bartlett's sphericity test $=952.33$ ). In relation to psychological factors, the factor analysis of the main components of the psychological profile resulted in the retention of three factors: propensity to risk and innovation (eight items; Cronbach's $\alpha=.845$ ), self-control (three items; Cronbach's $\alpha=.703$ ) and autonomy (two items; Cronbach's $\alpha=.723)$. These factors account for $52.88 \%$ of the explained variance. All internal reliability results are above the acceptable level for index creation reliability $(\mathrm{KMO}=.918$; Bartlett's sphericity test $=3,799.71$ )

The factorial analysis for motivations for entrepreneurship led to the retention of two factors that account for $71.58 \%$ of the explained variance, with good internal reliability results. The matrix of the components was also subjected to a varimax rotation (see Table 2).

As can be seen in Table 3, the factorial solution for the items related to entrepreneurial skills led to the retention of a single factor. This 
is associated with $69.48 \%$ of the explained variance and an extremely good result from the internal reliability analysis (Cronbach's $\alpha=.911$ ).

TABLE 1 Results of factor analysis of main components of organisations' internal conditions

\begin{tabular}{|c|c|}
\hline \multicolumn{2}{|l|}{ Dimensions } \\
\hline \multicolumn{2}{|c|}{ Administrator/coordinator support (18 items) } \\
\hline Explained variance & $51.76 \%$ \\
\hline $\mathrm{KMO}$ & 0.949 \\
\hline Bartlett's sphericity test & $7,816.79$ \\
\hline Cronbach's $\alpha$ & 0.949 \\
\hline \multicolumn{2}{|c|}{ Operational autonomy (7 items) } \\
\hline Explained variance & $47.97 \%$ \\
\hline KMO & 0.875 \\
\hline Bartlett's sphericity test & $2,287.95$ \\
\hline Cronbach's $\alpha$ & 0.879 \\
\hline \multicolumn{2}{|l|}{ Rewards (5 items) } \\
\hline Explained variance & $63.79 \%$ \\
\hline KMO & 0.878 \\
\hline Bartlett's sphericity test & $2,101.61$ \\
\hline Cronbach's $\alpha$ & 0.880 \\
\hline \multicolumn{2}{|l|}{ Availability of time (4 items) } \\
\hline Explained variance & $42.53 \%$ \\
\hline KMO & 0.682 \\
\hline Bartlett's sphericity test & $1,002.46$ \\
\hline Cronbach's $\alpha$ & 0.790 \\
\hline \multicolumn{2}{|c|}{ Organisational procedures (6 items) } \\
\hline Explained variance & $37.81 \%$ \\
\hline $\mathrm{KMO}$ & 0.696 \\
\hline Bartlett's sphericity test & 819.79 \\
\hline Cronbach's $\alpha$ & 0.727 \\
\hline
\end{tabular}

KMO, Kaiser-Meyer-Olkin.

TABLE 2 Results of factor analysis of main components of motivations for entrepreneurship
The factor analysis of the items related to El resulted in the retention of a single factor, which accounts for $87.66 \%$ of the explained variance. This factor also produced extremely good result in the internal reliability analysis (Cronbach's $\alpha=.971$ ), as shown in Table 4 .

\section{3 | Linear regression model}

To respond to the objective defined for this study, the research hypotheses were verified using multiple linear regression models. These included $\mathrm{El}$ as the dependent variable and the independent variables of the entrepreneurial profile (i.e., motivations and cognitive, psychological, sociodemographic and professional factors, as well as entrepreneurial capacities) and organisations' internal conditions. The results are presented in Table 5 and Figure 2.

The results in Table 5 and Figure 2 can be divided into two large groups that can influence the nurses' El: (1) the factors that constitute the entrepreneurial profile, and (2) factors arising from organisations' internal conditions. Regarding nurse entrepreneurs, the results indicate that:

- The intrapreneurship motivations of self-realisation and family need and/or influence contribute positively to nurses' El.

- With regard to entrepreneurial skills, nurses with a higher level of entrepreneurial skills have a higher El.

- Regarding cognitive profile factors, an optimistic perception of success and the influence of affective states contribute positively to nurses' El.

- In the psychological profile, only the propensity to risk and innovation makes a statistically significant contribution to $\mathrm{El}$, and, the greater the respondents' propensity to risk and innovation manifested, the greater is their El.

- With regard to the sociodemographic and professional profile, being female means a lower El and being older also contributes negatively to $\mathrm{El}$, but having management training implies an increase in nurses' EI.

\begin{tabular}{|lcc} 
& \multicolumn{1}{c}{ Loadings } & \\
\cline { 2 - 3 } & Self-realisation & Need/family influence \\
\hline $\begin{array}{l}\text { To continue to learn and grow as a } \\
\text { person }\end{array}$ & 0.895 & \\
\hline $\begin{array}{l}\text { To achieve goals and be recognised for } \\
\text { this }\end{array}$ & 0.814 & \\
\hline To realise personal dreams & 0.894 & \\
\hline To direct and motivate third parties & 0.698 & 0.722 \\
\hline To challenge myself & 0.861 & 0.895 \\
\hline Due to family influence & & 0.855 \\
\hline Out of necessity & & \\
\hline For financial reasons & & \\
\hline Explained variance & & \\
\hline Kaiser-Meyer-Olkin & 2590.30 & 0.789 \\
\hline Bartlett's sphericity test & 0.898 & \\
\hline Cronbach's $\alpha$ & &
\end{tabular}


TABLE 3 Results of factor analysis of main components of entrepreneurial skills

\begin{tabular}{|lc|}
\hline & Loadings \\
\hline Recognition of opportunity & 0.770 \\
\hline Creativity & 0.824 \\
\hline Problem-solving skills & 0.851 \\
\hline Leadership and communication skills & 0.863 \\
\hline Development of new products and services & 0.849 \\
\hline Networking skills and making professional contacts & 0.840 \\
\hline Explained variance & $69.48 \%$ \\
\hline Kaiser-Meyer-Olkin & 0.888 \\
\hline Bartlett's sphericity test & $2,357.82$ \\
\hline Cronbach's $\alpha$ & 0.91 \\
\hline
\end{tabular}

TAB LE 4 Results of factor analysis of main components of entrepreneurship intention

\begin{tabular}{|lc|}
\hline I am ready to do anything to be an entrepreneur & Loadings \\
\hline My professional goal is to become an entrepreneur & 0.846 \\
\hline I will make every effort to start and run my own firm & 0.927 \\
\hline I am determined to create a firm in the future & 0.958 \\
\hline I have seriously thought of starting a firm & 0.966 \\
\hline I have a firm intention to start a business someday & 0.962 \\
\hline Explained variance & 0.952 \\
\hline Kaiser-Meyer-Olkin & $87.66 \%$ \\
\hline Bartlett's sphericity test & 0.928 \\
\hline Cronbach's $\alpha$ & $5,614.02$ \\
\hline
\end{tabular}

- Regarding organisations' internal conditions, the results verified that only the dimension of operational autonomy has statistical significance: the greater the autonomy granted by the health organisation to the nurse, the higher the level of El within the organisation.

\section{5 | DISCUSSION}

Ferreira et al. (2013) identified individuals' permanent need to design, create and carry out activities proactively and the skills to deal with and motivate people as entrepreneurial characteristics. The present study sought to fill the gap in the literature arising from the lack of studies testing instruments capable of measuring quantitatively these personal and organisational characteristics in a specific professional area such as health care-in this case nurses. To this end, this section starts by presenting the results for verification of the research hypotheses.

A positive relationship exists between operational autonomy and respondents' El, thus reinforcing the conclusions of some authors who argue that individuals with greater autonomy at work have a higher level of El (Hornsby, Naftziger, Kuratko, \& Montagno, 1993; Kuratko et al., 2014): confirm $\mathrm{H}_{1}$. The data offer support for $\mathrm{H}_{2}$ as the analysis verified that being female means lower El levels and that a more advanced age contributes negatively to El. In contrast, having training in management means a higher level of El, which is in agreement with previous studies (Antoncic \& Hisrich, 2003; Martiarena, 2013; Rodrigues, Raposo, Ferreira, \& Paço, 2008; Urbano, Alvarez, \& Turró, 2013).

The results of the present study provide support for $\mathrm{H}_{3}$ so that, the higher the risk and innovation propensity manifested by respondents, the higher their El, as suggested by the studies reviewed (Martiarena, 2013; Rodrigues et al., 2008; Urbano et al., 2013). As the factors of optimistic perception of success and influence of affective states contribute positively to El, as argued by Marques et al. (2013) and Lages et al. (2016), $\mathrm{H}_{4}$ was also confirmed. Based on the present results, $\mathrm{H}_{5}$ is confirmed given that self-actualisation and family need and/or influence contribute positively to El. This has been corroborated by previous studies (Antoncic \& Hisrich, 2003; Baron, 2004; Rodrigues et al., 2008). The final hypothesis was also confirmed as the data verified that the higher the level of entrepreneurial skills of nurses the higher their El is. This confirms the findings of previous research (Phipps et al., 2015).

In short, the only positive relationship found is between operational autonomy and nurses' El, thus reinforcing the conclusion reached by some other researchers that individuals with greater operational autonomy at work have a higher level of El (Hornsby et al., 1993; Kuratko et al., 2014). Five factors that come from the entrepreneurial profile of nurses contribute the most to nurses' El. First, management training means a higher level of nurses' El (Martiarena, 2013; Urbano et al., 2013). Second, the higher the risk and innovation propensity manifested by nurses, the higher their El is (Martiarena, 2013; Urbano et al., 2013). Third, nurses' optimistic perceptions of future success and the nurses' affective states contribute positively to their El (Lages et al., 2016; Marques et al., 2013). Fourth, self-actualisation and family need and/or influence have a positive effect on nurses' EI (Baron, 2004; Rodrigues et al., 2008). Last, the higher the level of nurses' entrepreneurial skills, the higher their El is (Phipps et al., 2015).

The present study's results contrast with Weng, Huang, Chen, and Chang (2015) finding that organisational climate and managers contribute significantly to innovation behaviour and an innovation climate. All support provided by organisations is crucial to increasing innovation and intrapreneurial behaviour. The present results, therefore, suggest that the organisations under study have not adopted strategic management models that encourage the dissemination and implementation of innovation processes and intrapreneurship. This could be why the El of the nurses in question is explained mostly by individual traits.

\section{6 | CONCLUSIONS}

Health care organisations must support nurses who present innovative ideas and initiatives and who, in the present study, were referred to as intrapreneurs. As noted by Lumpkin and Dess (1996), any discussion of intrapreneurship needs to involve aspects related to both personal and organisational characteristics. Alpkan, Bulut, 
TAB LE 5 Linear regression models for predicting entrepreneurship intention

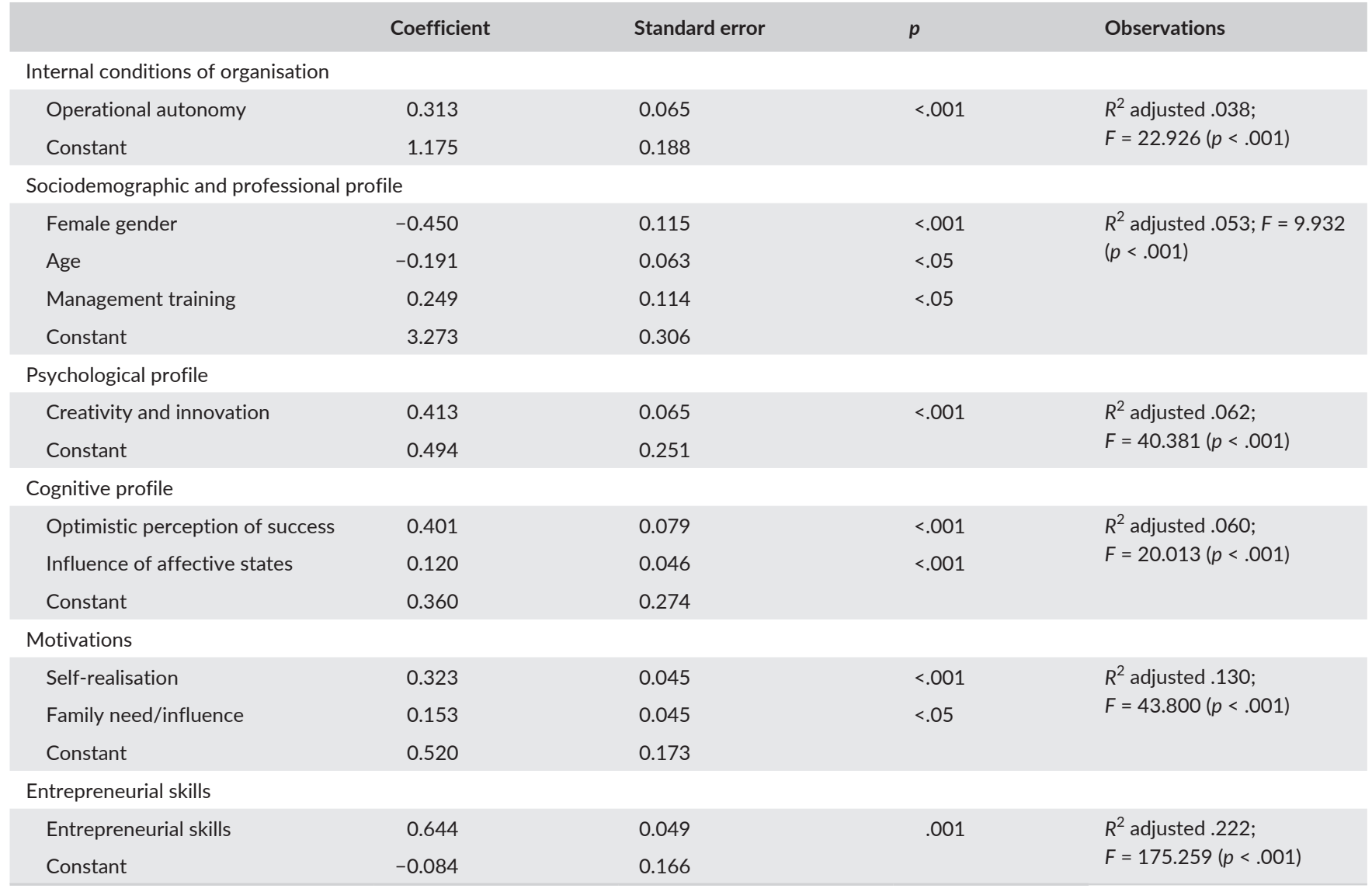

Sociodemographic and professional profile

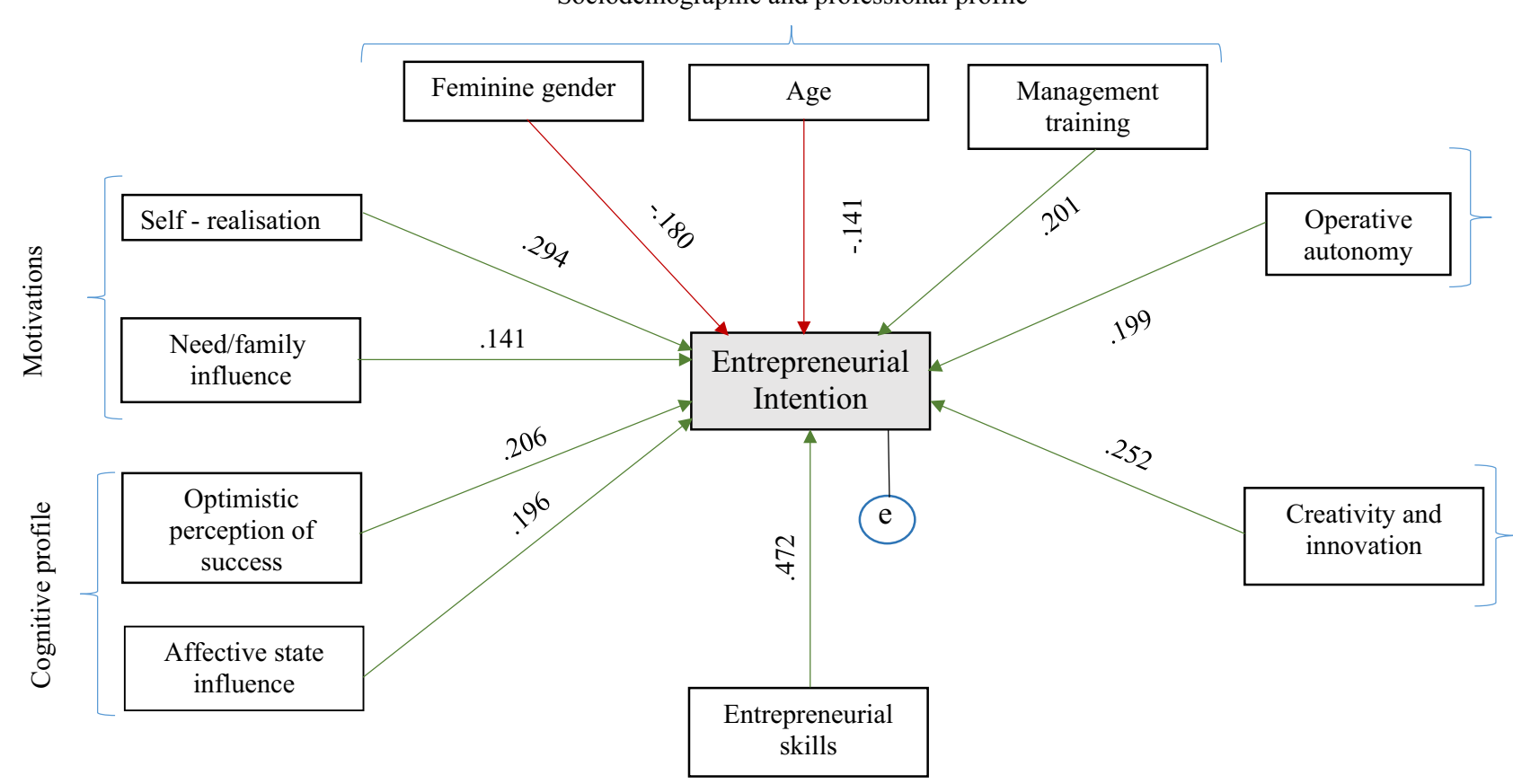

FIGURE 2 Linear regression models for predicting entrepreneurial intention [Colour figure can be viewed at wileyonlinelibrary.com] 
Gunday, Ulusoy, and Kilic (2010) and Kuratko et al. (2014) further underline that, for intrapreneurs to emerge, proper organisational internal conditions are needed in which the entrepreneurial spirit is valued. According to the cited authors, organisations have to give the development of an intrapreneurial culture priority as this in turn can give rise to innovative approaches that enhance employees' creative capacities.

Based on the research question formulated (i.e., How do personal and organisational factors influence nurses' El?), the present study sought to contribute to a fuller understanding of El in health care services. The results support the conclusion that the internal conditions of organisations are the dimension that most significantly stands out as a catalyst of nurses' entrepreneurial behaviour.

Given the limited previous research in this area, Sankelo and Åkerblad (2008), not unexpectedly, report little research has been done on nurse entrepreneurs with either a focus on management or any other emphasis. The present study could stimulate other scholars' interest in conducting future studies in this field because the present results confirm the great potential for research on this subject. Weng et al. (2015) have already suggested that researchers need to investigate a large-scale data set from various national nursing contexts. Thus, due to the pioneering nature and singularity of the present study-in addition to its other merits-its findings are a significant contribution to the literature on El and health care organisations. This research could also have future implications for both the scientific community and health care organisations.

A study of this nature always entails some limitations. One limitation observed was that the questionnaires were only distributed to nurses in two public hospitals in a northern region of Portugal. Future research could extend this study's approach to organisations from other regions of Portugal and carry out comparative studies with other types of institutions, particularly those of the third and private sectors. A second limitation is the weak, mediating, role of motivation in our model. Future research could include other motivational factors that may be more strongly related to entrepreneurship within health care organisations. A third limitation of this study, which paves the way for future research is that we find, despite the scales used have already been applied to the health care sector (Lages et al., 2016; Marques et al., 2013), confirm findings from the study by Lages et al. (2016) referring the need to develop specific scales for this sector, particularly the scales of El and internal conditions of organisation, as its scales used so far are validated and used mostly in industry sectors.

\section{7 | IMPLICATIONS FOR NURSING MANAGEMENT}

Organisational research is clearly important to the health care system, in particular when assessing the impacts of nursing, because most nurses perform functions in complex organisational contexts (Aiken \& Patrician, 2000). The importance of this study lies in how it recognises nurses as potential entrepreneurs, as well as the influence of health care organisations' internal conditions that support entrepreneurship. Concerning this research's practical implications, the proposed conceptual framework could help top administrators and middle managers of health care organisations to understand better the link between internal conditions of organisations and $\mathrm{El}$ and, as a result, develop activities that enhance nurses' El.

Making intrapreneurship a top priority in organisational strategies may appear risky, but Toftoy and Chatterjee (2004) suggest that intrapreneurship has to start somewhere. Any health care organisation, regardless of their size and structure must experiment with and adopt intrapreneurial strategies. New models that encourage the dissemination and implementation of intrapreneurship and that are adapted to the specificities of health care organisations need to be applied. These should include middle managers and nurses lower in the hierarchy who can identify opportunities for innovation and implement innovations with the support of top management. Weng et al. (2015) supports this suggestion for nursing management by emphasising that managers need to encourage and pay attention to nurses' creative and innovative behaviours and provide substantive, sustained support and rewards for new ideas and applications.

Intrapreneurship is a bilateral process-top-down (i.e., internal conditions promoted by top and middle managers) and bottom-up (i.e., nurses fitting the intrapreneurial profile)-that ensures all work together, learn from experimentation and constantly striving to improve. The adoption and practice of intrapreneurial activities need, therefore, to be encouraged strongly to attain competitive advantages, and this is the responsibility of both top management and nurse intrapreneurs. The challenges of intrapreneurship should be tackled not only by developing a sincere managerial commitment among leaders at the top of organisations but also by encouraging nurse intrapreneurs' personal dedication.

\section{ACKNOWLEDGEMENTS}

This work was supported by European structural and investment funds through the European Regional Development Fund's 'Competitiveness and Internationalization' Operational Program (COMPETE 2020: Project No. 006971 [UID/SOC/04011]) and by national funds through the Portuguese Foundation for Science and Technology (FCT) (Project UID/SOC/04011/2013).

\section{ORCID}

Carla S. Marques (iD http://orcid.org/0000-0003-1557-1319

\section{REFERENCES}

Adeyemo, S. A. (2009). Understanding and acquisition of entrepreneurial skills: A pedagogical re-orientation for classroom teacher in science education. Journal of Turkish Science Education, 6(3), 57.

Aiken, L. H., \& Patrician, P. A. (2000). Measuring organizational traits of hospitals: The Revised Nursing Work Index. Nursing Research, 49(3), 146-153. https://doi.org/10.1097/00006199-200005000-00006

Alpkan, L., Bulut, C., Gunday, G., Ulusoy, G., \& Kilic, K. (2010). Organizational support for intrapreneurship and its interaction with human capital to 
enhance innovative performance. Management Decision, 48(5), 732755. https://doi.org/10.1108/00251741011043902

Antoncic, B., \& Hisrich, R. (2003). Clarifying the intrapreneurship concept. Journal of Small Business and Enterprise Development, 10, 7-24. https:// doi.org/10.1108/14626000310461187

Baron, R. (2004). Potential benefits of the cognitive perspective: Expanding entrepreneurship's array of conceptual tools. Journal of Business Venturing, 19, 169-172. https://doi.org/10.1016/S0883-9026(03)00004-1

Bhardwaj, B. R., \& Sushil (2012). Internal environment for corporate entrepreneurship: Assessing CEAl model for emerging economies. Journal of Chinese Entrepreneurship, 4, 70-87. https://doi. org/10.1108/17561391211200948

Bosma, N., Stam, E., \& Wennekers, S. (2011). Intrapreneurship versus independent entrepreneurship: A cross-national analysis of individual entrepreneurial behaviour. Discussion Papers, Utrecht University School of Economics, Utrecht, the Netherlands. Retrieved from http://www. uu.nl/rebo/economie/discussionpapers (Accessed 14 July 2017).

Cadar, O., \& Badulescu, D. (2015). Entrepreneur, entrepreneurship and intrapreneurship: A literature review. The Annals of University of Oradea, Economic Sciences, 24(2), 658-664.

Chedli, M. K. E. (2016). Entrepreneurial motivation and performance of enterprises. Economics, Management and Financial Markets, 11, 175.

Chen, M. H., Chang, Y. Y., \& Lo, Y. H. (2015). Creativity cognitive style, conflict, and career success for creative entrepreneurs. Journal of Business Research, 68(4), 906-910. https://doi.org/10.1016/j. jbusres.2014.11.050

Costa, F. G., Martinello, D. F. G., Vaghetti, H. H., Mendes, D. P., Terra, A. C., Alvarez, S. Q., \& Lemos, L. A. P. (2013). Tendências empreendedoras dos enfermeiros de um hospital universitário. Revista Gaúcha de Enfermagem, 34(3), 147-154. https://doi.org/10.1590/ S1983-14472013000300019

Darbyshire, P. (2014). An idea whose time has come: Nursing entrepreneurialism. Whitireia Nursing \& Health Journal, 21, 9-14.

Debarliev, S., Janeska-lliev, A., Bozhinovska, T., \& Ilieva, V. (2015). Antecedents of entrepreneurial intention: Evidence from Republic of Macedonia. Business and Economic Horizons, 11(3), 143-161. https:// doi.org/10.15208/beh

DeSantis, K., \& Scales, T. W. (2015). NEW (nurse entrepreneurship worldwide). Academy of Business Research Journal, 4, 92.

Erdmann, A. L., Fernandes, J. V., Melo, C., Carvalho, B. R., Menezes, Q., Freitas, R. D., \& Backes, M. T. S. (2009). A visibilidade da profissão de enfermeiro: Reconhecendo conquistas e lacunas. Revista Brasileira de Enfermagem, 62(4), 637-643. https://doi.org/10.1590/ S0034-71672009000400025

Fayolle, A., \& Liñán, F. (2014). The future of research on entrepreneurial intentions. Journal of Business Research, 67(5), 663-666. https://doi. org/10.1016/j.jbusres.2013.11.024

Fayolle, A., Liñán, F., \& Moriano, J. (2014). Beyond entrepreneurial intentions: Values and motivations in entrepreneurship. International Entrepreneurship and Management Journal, 10(4), 679-689. https://doi. org/10.1007/s11365-014-0306-7

Fernandéz, J., Liñán, F., \& Santos, F. (2009). Cognitive aspects of potential entrepreneurs in southern and northern Europe, an analysis using GEM-data. Revista de Economia Mundial, 23, 151-178.

Ferreira, G. E., Rozendo, C. A., dos Santos, R. M., Pinto, E. A., Costa, A. C. S., \& Porto, A. R. (2013). Características empreendedoras do futuro enfermeiro. Cogitare Enfermagem, 18(4), 688-694.

Holland, D. V., \& Shepherd, D. A. (2013). Deciding to persist: Adversity, values, and entrepreneurs' decision policies. Entrepreneurship Theory and Practice, 37(2), 331-358. https://doi. org/10.1111/j.1540-6520.2011.00468.x

Hornsby, J., Kuratko, D., Shepherd, D., \& Bott, J. (2009). Managers' corporate entrepreneurial actions: Examining perception and position. Journal of Business Venturing, 24(3), 236-247. https://doi.org/10.1016/j. jbusvent.2008.03.002
Hornsby, S., Naftziger, W., Kuratko, F., \& Montagno, V. (1993). An interactive model of the corporate entrepreneurship process. Entrepreneurship: Theory and Practice, 17(2), 29-37.

Ibrahim, N. A., \& Lucky, E. O. I. (2014). Relationship between entrepreneurial orientation, entrepreneurial skills, environmental factor and entrepreneurial intention among Nigerian students in UUM. Entrepreneurship and Innovation Management Journal, 2(4), 203-213.

Indarti, N., \& Rostiani, R. (2008). Students' intentions of entrepreneurship: A comparison study between Indonesia, Japan, and Norway. Jurnal Ekonomika dan Bisnis Indonesia, 23(4), 1-27.

Ismail, K., Anuar, M. A., Omar, W. W., Aziz, A. A., Seohod, K., \& Akhtar, C. S. (2015). Entrepreneurial intention, entrepreneurial orientation of faculty and students towards commercialization. Procedia-Social and Behavioral Sciences, 181, 349-355. https://doi.org/10.1016/j.sbspro.2015.04.897

Jong, J. D., \& Wennekers, S. (2008). Intrapreneurship: conceptualizing entrepreneurial employee behavior. Scientific Analysis of Entrepreneurship and SMEs(SCALES) Research Reports. Retrieved from http://www.entrepreneurship-sme.eu/pdf-ez/H200802.pdf (Accessed 11 July 2017).

Karimi, S., Biemans, H. J. A., Mahdei, K. N., Lans, T., Chizari, T., \& Mulder, M. (2017). Testing the relationship between personality characteristics, contextual factors and entrepreneurial intentions in a developing country. International Journal of Psychology, 52(3), 227-240. https://doi. org/10.1002/ijop.12209

Karyotakis, K. M., \& Moustakis, V. S. (2015). Innovating in public administration. Paper presented at the 12th Student Conference of Science and Technology, Athens University of Economics and Business \& Hellenic Management Association, Athens, 14 May (pp. 114-124). (in Greek)

Karyotakis, K. M., \& Moustakis, V. S. (2016). Organizational factors, organizational culture, job satisfaction and entrepreneurial orientation in public administration. The European Journal of Applied Economics, 13, 47-59. https://doi.org/10.5937/ejae13-10781

Krueger, N. F., Reilly, M. D., \& Carsrud, A. L. (2000). Competing models of entrepreneurial intentions. Journal of Business Venturing, 15(5), 411432. https://doi.org/10.1016/S0883-9026(98)00033-0

Kuratko, D., Hornsby, J., \& Covin, J. (2014). Diagnosing a firm's internal environment for corporate entrepreneurship. Business Horizons, 57, 37-47. https://doi.org/10.1016/j.bushor.2013.08.009

Kuratko, D., Ireland, R., \& Hornsby, J. (2001). Improving firm performance through entrepreneurial actions: Acordia's corporate entrepreneurship strategy. Academy of Management Executive, 15(4), 60-71. https://doi. org/10.5465/AME.2001.5897658

Kusmintarti, A., Thoyib, A., Maskie, G., \& Ashar, K. (2016). Entrepreneurial characteristics as a mediation of entrepreneurial education influence on entrepreneurial intention. Journal of Entrepreneurship Education, 19, 24.

Lages, M., Marques, C. S., Ferreira, J., \& Ferreira, F. (2016). Intrapreneurship and firm entrepreneurial orientation: Insights from the health care service industry. International Entrepreneurship and Management Journal, 13(3), 837-854. https://doi.org/10.1007/s11365-016-0428-1

Liñán, F. (2008). Skill and value perceptions: How do they affect entrepreneurial intentions? International Entrepreneurship and Management Journal, 4(3), 257-272. https://doi.org/10.1007/s11365-008-0093-0

Liñán, F., \& Chen, Y. W. (2009). Development and cross-cultural application of a specific instrument to measure entrepreneurial intentions. Entrepreneurship Theory and Practice, 33(3), 593-617. https://doi. org/10.1111/j.1540-6520.2009.00318.x

Liñán, F., Cohard, J., \& Cantuche, J. (2011). Factors affecting entrepreneurial intention levels: A role for education. Entrepreneurial Management Journal, 7, 195-218. https://doi.org/10.1007/s11365-010-0154-z

Liñán, F., \& Fayolle, A. (2015). A systematic literature review on entrepreneurial intentions: Citation, thematic analyses, and research agenda. International Entrepreneurship and Management Journal, 11(4), 907933. https://doi.org/10.1007/s11365-015-0356-5

Lumpkin, G., \& Dess, G. (1996). Clarifying the entrepreneurial orientation construct and linking the performance. Academy of Management Review, 21, 135-172. 
Marques, C. S., Ferreira, J.J., Ferreira, F.A., \& Lages, M. F. (2013). Entrepreneurial orientation and motivation to start up a business: Evidence from the health service industry. International Entrepreneurship and Management Journal, 9, 77-94. https://doi.org/10.1007/s11365-012-0243-2

Martiarena, A. (2013). What's so entrepreneurial about intrapreneurs? Small Business Economics, 40, 27-39. https://doi.org/10.1007/ s11187-011-9348-1

Muehlfeld, K., Urbig, D., \& Weitzel, U. (2017). Entrepreneurs' exploratory perseverance in learning settings. Entrepreneurship Theory and Practice, 41(4), 533-565. https://doi.org/10.1111/etap.12224

Nabi, G., \& Liñán, F. (2011). Graduate entrepreneurship in the developing world: Intentions, education and development. Education and Training, 53, 325-334. https://doi.org/10.1108/00400911111147668

Patel, P. C., \& Thatcher, S. M. (2014). Sticking it out individual attributes and persistence in self-employment. Journal of Management, 40(7), 19321979. https://doi.org/10.1177/0149206312446643

Pejić Bach, M., Merkač Skok, M., \& Suša, D. (2016). Determinants of entrepreneurial intentions in ICT industry: Gender and country of origin perspective. Naše Gospodarstvo/Our Economy, 62, 37-45.

Phipps, S. T., Prieto, L. C., \& Kungu, K. K. (2015). Exploring the influence of creativity and political skill on entrepreneurial intentions among men and women: A comparison between Kenya and the United States. International Journal of Entrepreneurship, 19, 179.

Rodrigues, G., Raposo, M., Ferreira, J., \& Paço, A. (2008). Entrepreneurship education and business creation propensity: Testing a structural model. International Journal Entrepreneurship and Small Business, 4(4), 485-504.

Romero-Martínez, A. M., \& Milone, M. (2016). El emprendimiento en España: Intención emprendedora, motivaciones y obstáculos. Revista de Globalización, Competitividad y Gobernabilidad, 1, 95.

Sankelo, M., \& Åkerblad, L. (2008). Nurse entrepreneurs' attitudes to management, their adoption of the manager's role and managerial assertiveness. Journal of Nursing Management, 16(7), 829-836. https://doi. org/10.1111/j.1365-2834.2008.00917.x

Shapero, A. (1984). The entrepreneurial event. In C. A. Kent (ed.), The Environment for Entrepreneurship. Lexington, MA: Lexington Books.

Shapero, A., \& Sokol, L. (1982). The social dimensions of entrepreneurship. In C.A. Kent, D. L. Sexton \& K. H. Vesper (Eds.), Encyclopedia of entrepreneurship (pp. 72-90). Englewood Cliffs, NJ: Prentice-Hall.

Singh, B., Verma, P., \& Rao, M. K. (2016). Influence of individual and sociocultural factors on entrepreneurial intention. South Asian Journal of Management, 23, 33-55.

Smith, L., Rees, P., \& Murray, N. (2016). Turning entrepreneurs into intrapreneurs: Thomas Cook, a case-study. Tourism Management, 56, 191-204. https://doi.org/10.1016/j.tourman.2016.04.005
Tang, J., Tang, Z., \& Lohrke, F. (2007). Developing an entrepreneurial typology: The roles of entrepreneurial alertness and attributional style. International Entrepreneurship and Management Journal, 4(3), 273-294.

Thompson, E. R. (2009). Individual entrepreneurial intent: Construct clarification and development of an internationally reliable metric. Entrepreneurship Theory and Practice, 33(3), 669-694. https://doi. org/10.1111/j.1540-6520.2009.00321.x

Toftoy, C., \& Chatterjee, J. (2004). The intrapreneurial revolution: Now is the time for action. Retrieved from http://sbaer.uca.edu/research/ icsb/2005.../paper192.pdf (Accessed 11 July 2017).

Urbano, D., Alvarez, C., \& Turró, A. (2013). Organizational resources and intrapreneurial activities: An international study. Management Decision, 51(4), 854-870. https://doi.org/10.1108/00251741311326617

Verheul, I., Thurik, R., Grilo, I., \& Van der Zwan, P. (2012). Explaining preferences and actual involvement in self-employment: Gender and the entrepreneurial personality. Journal of Economic Psychology, 33(2), 325-341. https://doi.org/10.1016/j.joep.2011.02.009

Virick, M., Basu, A., \& Rogers, A. (2015). Antecedents of entrepreneurial intention among laid-off individuals: A cognitive appraisal approach. Journal of Small Business Management, 53(2), 450-468. https://doi. org/10.1111/jsbm.12067

Weng, R. H., Huang, C. Y., Chen, L. M., \& Chang, L. Y. (2015). Exploring the impact of transformational leadership on nurse innovation behaviour: $A$ cross-sectional study. Journal of Nursing Management, 23(4), 427-439. https://doi.org/10.1111/jonm.12149

Zapkau, F. B., Schwens, C., Steinmetz, H., \& Kabst, R. (2015). Disentangling the effect of prior entrepreneurial exposure on entrepreneurial intention. Journal of Business Research, 68(3), 639-653. https://doi. org/10.1016/j.jbusres.2014.08.007

\section{SUPPORTING INFORMATION}

Additional Supporting Information may be found online in the supporting information tab for this article.

How to cite this article: Marques CS, Valente S, Lages M. The influence of personal and organisational factors on entrepreneurship intention: An application in the health care sector. J Nurs Manag. 2018;26:696-706. https://doi. org/10.1111/jonm.12604 